\title{
Expression of an inducible Enzyme II fructose and activation of a cryptic Enzyme II glucose in glucose-grown cells of spontaneous mutants of Streptococcus salivarius lacking the low-molecular-mass form of III ${ }^{\text {man }}$, a component of the phosphoenolpyruvate:mannose phosphotransferase system
}

\author{
Sylvie Bourassa and Christian Vadeboncoeur* \\ Groupe de Recherche en Ecologie Buccale (GREB), Department of Biochemistry (Sciences) and Dental School, \\ Université Laval, Québec, Canada G1K 7 P4
}

(Received 6 August 1991; revised 29 October 1991; accepted 4 December 1991)

\begin{abstract}
We have reported previously that the phosphoenolpyruvate:mannose phosphotransferase system (mannose PTS) of Streptococcus salivarius, consisting of an Enzyme II mannose (EII ${ }^{\text {man }}$ ) and two forms of Enzyme III mannose (III ${ }^{\text {man }}$ ) with $M_{\mathrm{r}}$ values of 38900 and 35200 , respectively, concomitantly transports and phosphorylates mannose, as well as glucose and fructose. In this paper, we report the presence, in $S$. salivarius, of alternative specific fructose and glucose PTSs encoded by inducible and cryptic genes, respectively. Protein phosphorylation experiments conducted with ${ }^{32}$ P]phosphoenolpyruvate have allowed us to identify by SDS-PAGE and autoradiography the EII fructose (EII fru $)\left(M_{\mathrm{r}} 57500\right)$ and the EII glucose $\left(E I^{9 l c}\right)\left(M_{\mathrm{r}} 58700\right)$. No proteins corresponding to III ${ }^{\text {fru }}$ or III ${ }^{\text {glc }}$ could be detected. EII fru phosphorylated fructose on the $\mathrm{C}-1$ position rather than, as with the constitutive mannose PTS, on the C-6 position. Growth on fructose resulted in the induction of EII iru as well as an increase of 1-phosphofructokinase activity. Nevertheless, the genes encoding these proteins were independently regulated. Studies carried out with spontaneous mutants lacking the low-molecular-mass form of IIIman (mutants A37, G29 and B31) showed that EII fru was expressed in glucose-grown cells of strains G29 and B31, but not in strain A37, whereas the cryptic gene encoding EIIglc was activated in all three mutant strains. The results obtained with the mutants suggest that the three spontaneous mutants were not all mutated on the gene encoding IIIman although all of them lacked IIIman.
\end{abstract}

\section{Introduction}

The phosphoenolpyruvate:sugar phosphotransferase system (PTS) is the principal means by which Grampositive streptococci take up sugars (Thompson, 1987; Reizer et al., 1988). The PTS catalyses the concomitant transport and phosphorylation of mono- and disaccharides at the expense of phosphoenolpyruvate (PEP). The system consists of two general proteins ( $\mathrm{HPr}$ and $\mathrm{EI}$ ) that are required for the transport of all PTS sugars, as well as a family of specific permeases consisting of one or several polypeptide chains, commonly referred to as Enzyme II (EII) and Enzyme III (III) (Meadow et al.,
1990). Little information, however, is available on these specific PTS components in streptococci.

We recently characterized the mannose PTS of the oral bacterium Streptococcus salivarius (Vadeboncoeur \& Gauthier, 1987; Bourassa et al., 1990). This constitutive system transports mannose, as well as glucose and fructose, and consists of a membrane-bound EII mannose (EII $\left.{ }^{\text {man }}\right)$ and a III mannose (III $\left.{ }^{\text {man }}\right)$ that is found in the cytoplasm as well as being associated with the membrane. The III Iman complex of $S$. salivarius consists of two different polypeptides having $M_{\mathrm{r}}$ values of 38900 and 35200 . Spontaneous mutants of $S$. salivarius resistant to 2-deoxyglucose (2DG) and lacking the low-molecular-

- Author for correspondence. Tel. (418) 656 2319; fax (418) 6563664.

Abbreviations: 2DG, 2-deoxyglucose; EI and HPr, general sugar transport proteins; EII and III, Enzyme II and Enzyme III; FDP, fructose 1,6diphosphate; F1P and F6P, fructose 1- and 6-phosphate; FPr, fructose-specific HPr protein; fru, fructose; glc, glucose; man, mannose; PEP, phosphoenolpyruvate; 1- and 6-PFK, 1- and 6-phosphofructokinase; PTS, PEP : sugar phosphotransferase transport system; III ${ }^{\text {man }}$, low-molecularmass form of Enzyme III mannose. 
mass form of III ${ }^{\text {man }}$ (III $\mathrm{L}^{\text {man }}$ ) were recently characterized (Gauthier et al., 1990). These mutants did not grow on mannose and were unable to catalyse the PEP-dependent phosphorylation of mannose; however, they conserved high levels of EII fructose (EII fru) and EII glucose (EII ${ }^{\text {glc }}$ ) activities suggesting the presence of alternative fructose and glucose PTSs in these cells. The work presented here establishes the presence of an inducible EII fru and of a cryptic EII ${ }^{\text {lc }}$ in $S$. salivarius.

\section{Methods}

Bacterial strains and growth conditions. The parental strain used in this study was Streptococcus salivarius ATCC 25975 and was provided by Dr I. R. Hamilton (University of Manitoba, Canada). The mutant strains G29, B31 and A37 were isolated by positive selection for resistance to $0.5 \mathrm{~mm}-2 \mathrm{DG}$ in the presence of $11 \mathrm{~mm}$-lactose as previously described (Vadeboncoeur, 1984). Bacteria were grown at $37^{\circ} \mathrm{C}$ in a medium containing (per litre): $17 \mathrm{~g}$ Trypticase, $3 \mathrm{~g}$ yeast extract, $5 \mathrm{~g} \mathrm{NaCl}, 2.5 \mathrm{~g}$ disodium phosphate and 2 or $5 \mathrm{~g}$ sugar.

PTS components. EI and HPr were purified from $S$. salivarius ATCC 25975 according to the method of Rodrigue $e t$ al. (1988). Membranes containing the EII ${ }^{\text {man }} / \mathrm{III}^{\text {man }}$ complex and the other EIIs were prepared as described previously (Vadeboncoeur \& Gauthier, 1987).

Enzyme assays. 6-Phosphofructokinase (6-PFK) and 1-phosphofructokinase (1-PFK) activities were measured by a reaction coupled to NADH oxidation as described by Conrad \& Schlegel (1977) using cell extracts prepared by sonication (Vadeboncoeur et al., 1982). EII activity in membrane fractions was assayed with ${ }^{14} \mathrm{C}$-labelled sugar substrates in the presence of excess purified EI and HPr and the isolation of the radioactively labelled sugar phosphates by precipitation with $\mathrm{BaBr}_{2}$ (Vadeboncoeur, 1984).

Uptake experiments. The uptake of $\left[{ }^{14} \mathrm{C}\right]$ fructose and $\left[{ }^{14} \mathrm{C}\right]$ glucose by cells was performed as described by Vadeboncoeur \& Trahan (1982) with slight modification. When uptake experiments were carried out at room temperature, the rate of sugar uptake was too rapid to permit the determination of initial rates. Experiments were therefore conducted at $10^{\circ} \mathrm{C}$. The uptake was initiated by adding $233 \mu \mathrm{l}$ of the cell suspension ( $75 \mathrm{mg}$ wet weight $\mathrm{ml}^{-1}$ ) to a medium $(10 \mathrm{ml})$ containing $50 \mathrm{mM}$-sodium phosphate buffer $\left(\mathrm{pH} \mathrm{7.0)}, 10 \mathrm{~mm}\right.$-iodoacetate and $0.05 \mathrm{mM}^{-14} \mathrm{C}$ labelled sugar $\left[1 \mu \mathrm{Ci} \mu \mathrm{mol}^{-1}\left(37 \mathrm{kBq} \mu \mathrm{mol}^{-1}\right)\right]$. For inhibition studies, $0.25 \mathrm{~mm}$ of the unlabelled test sugar was added to the reaction medium. At various times, $1.0 \mathrm{ml}$ samples were filtered through a Millipore filter (type HA, pore size $0.45 \mu \mathrm{m}$ ) and washed with $5 \mathrm{ml}$ sodium phosphate buffer.

Western blot procedures. Proteins were subjected to electrophoresis according to the method of Laemmli (1970) and then transferred electrophoretically to nitrocellulose paper $(0.45 \mu \mathrm{m}$ pore size $)$ in $25 \mathrm{~mm}$ Tris, $192 \mathrm{~mm}$-glycine, $20 \%(\mathrm{v} / \mathrm{v})$ methanol buffer ( $\mathrm{pH} 8.3)$ according to the method of Towbin et al. (1979). Blotting was done as described by Bio-Rad.

Paper chromatography. Fructose-6-phosphate (F6P) and fructose1-phosphate (F1P) were identified by paper chromatography on Whatman no. 1 paper using $1 \mathrm{M}$-ammonium acetate (pH 5.0)/95\% ethanol/0.1 mM-EDTA (30:70:1 by vol.) as solvent (Gauthier $e$ t al., 1984).

Phosphorylation of proteins using $\left[{ }^{32} P\right] P E P .\left[{ }^{32} \mathrm{P}\right] \mathrm{PEP}$ was synthesized from $\left[\gamma^{-32}\right.$ P $]$ ATP using purified PEP carboxykinase from Escherichia coli K12 (kindly provided by $\mathrm{Dr} \mathrm{A}$. H. Goldie, University of
Saskatchewan, Canada) as described by Mattoo \& Waygood (1983). The procedure of Waygood et al. (1986) for the phosphorylation of proteins was followed with slight modification. Samples were incubated for $6 \mathrm{~min}$ at room temperature in $60 \mu \mathrm{l}$ of a medium containing $0 \cdot 1 \mathrm{mM}-\left[{ }^{32} \mathrm{P}\right] \mathrm{PEP} \quad\left(10^{6}\right.$ c.p.m. nmol $\left.{ }^{-1}\right), 5 \mathrm{mM}-\mathrm{MgCl}_{2}$, $12.5 \mathrm{~mm}-\mathrm{NaF}$ and $0.01 \mathrm{M}-\mathrm{HEPES} / \mathrm{NaOH}(\mathrm{pH} 7.5$ ). Fresh membrane preparations $(150 \mu \mathrm{g}$ protein), $1 \mu \mathrm{g}$ EI and $3 \mu \mathrm{g} \mathrm{HPr}$ from $S$. salivarius were usually used. The reaction was stopped by the addition of $20 \mu \mathrm{l}$ of a solution containing $0.188 \mathrm{M}$-Tris/ $\mathrm{HCl}(\mathrm{pH} 8.0), 6 \%$ (w/v) SDS, $30 \%$ (v/v) glycerol, 6\% (v/v) 2-mercaptoethanol and $5 \mu \mathrm{l} 0.005 \%$ bromophenol blue. Samples were loaded on a 10 or $12 \%(\mathrm{w} / \mathrm{v})$ acrylamide gel over a $30 \mathrm{~min}$ period during which the samples were kept at room temperature. A current of $15 \mathrm{~mA}$ per gel was applied during the migration through the stacking gel and $25 \mathrm{~mA}$ per gel during migration in the resolving gel. Phosphoproteins were detected by autoradiography of dried gels, performed at room temperature with Kodak X-ray film (X-Omat AR) with exposure times ranging from 5 to $18 \mathrm{~h}$.

Acid production. The rate of acid production by resting cells was monitored at $\mathrm{pH} 7.5$ with a Radiometer pH-stat system (pH meter PHM 64 in conjunction with a TTT60 titrator) by automatic titration with $0.2 \mathrm{M}-\mathrm{NaOH}$ of the acids produced. Acid production was initiated by the addition of $100 \mu \mathrm{mol}$ glucose (Vadeboncoeur \& Trahan, 1982).

Protein determination. Total protein was measured by Lowry's method. Bovine serum albumin was used as the standard. Membrane fragments were incubated for $20 \mathrm{~min}$ at $37^{\circ} \mathrm{C}$ in $1 \mathrm{M}-\mathrm{NaOH}$ prior to carrying out the protein assay.

\section{Results and Discussion}

\section{The inducible fructose PTS of S. salivarius}

We have already shown that fructose and mannose are substrates of the mannose PTS in $S$. salvarius (Vadeboncoeur, 1984; Bourassa et al., 1990). As shown in Table 1, the parental strain possessed, after growth on glucose, comparable EII activity for these two sugars. However, growth on fructose induced a twofold increase in EII fru activity and a threefold decrease in EIIman activity suggesting that mannose and fructose were phosphorylated by two distinct systems in fructose-grown cells. This hypothesis was supported by results obtained from uptake studies. The initial rate of fructose uptake by glucose-grown cells of the parental strain was reduced by $50 \%$ when a fivefold higher concentration of mannose was added to the reaction medium (data not shown). Mannose also decreased the initial rate of fructose uptake by fructose-grown cells, but to a lesser extent $(28 \%)$, suggesting that the mannose PTS was not the unique route of entry for fructose in these cells.

The presence of an inducible fructose PTS was confirmed by studies performed with mutants A37, B31 and G29 lacking III $\mathrm{L}^{\text {an }}$ (Bourassa et al., 1990). These strains are unable to grow on mannose and possess very little mannose PTS activity (Table 1). Strain A37 had lower EII fru activity than the parental strain after growth on glucose but the activity increased by a factor of eight following growth on fructose. Similarly, a low level of 
Table 1. EII activities for fructose, mannose and glucose in membranes of glucose- or fructose-grown cells of $S$. salivarius (wild-type) and mannose-PTS-negative mutants

The reaction mixture $(600 \mu \mathrm{l})$ contained $50 \mathrm{~mm}$-sodium phosphate (pH 7.0), $4 \mathrm{mM}-\mathrm{MgCl}_{2}, 2 \mathrm{mM}-\mathrm{PEP}, 5 \mathrm{mM}-2$-mercaptoethanol, $10 \mathrm{mM}-\mathrm{NaF}, 2 \mathrm{~mm}^{-14} \mathrm{C}$-labelled sugars $\left[0.1 \mu \mathrm{Ci}_{\mu \mathrm{mol}^{-1}}(37.5 \mathrm{kBq}\right.$ $\left.\mu \mathrm{mol}^{-1}\right)$ ], $375 \mu \mathrm{g} \mathrm{HPr}, 1 \mu \mathrm{g} \mathrm{EI}$, and membrane fragments $(50 \mu \mathrm{g}$ protein) as a source of EII and IIIman. Activities are expressed as nmol phosphorylated sugar ( $\mathrm{mg}$ of membrane protein $)^{-1}$ $(30 \mathrm{~min})^{-1}$. The values are the mean of two to three determinations $\pm \mathrm{SE}$, except for glucose PTS activity of fructose-grown cells of G29 and activities for fructose-grown cells of B31 for which only one determination was done.

\begin{tabular}{|c|c|c|c|c|}
\hline \multirow[b]{2}{*}{ Strain } & \multirow{2}{*}{$\begin{array}{l}\text { Growth } \\
\text { sugar }\end{array}$} & \multicolumn{3}{|c|}{ Ell activities for: } \\
\hline & & Fructose & Mannose & Glucose \\
\hline ATCC 25975 & $\begin{array}{l}\text { Glucose } \\
\text { Fructose }\end{array}$ & $\begin{array}{l}2487 \pm 256 \\
5621 \pm 772\end{array}$ & $\begin{array}{r}2697 \pm 217 \\
720 \pm 22\end{array}$ & $\begin{array}{r}1287 \pm 227 \\
783 \pm 189\end{array}$ \\
\hline A37 & $\begin{array}{l}\text { Glucose } \\
\text { Fructose }\end{array}$ & $\begin{array}{r}924 \pm 80 \\
8493 \pm 772\end{array}$ & $\begin{array}{r}56 \pm 10 \\
158 \pm 43\end{array}$ & $\begin{array}{r}1377 \pm 165 \\
130 \pm 27\end{array}$ \\
\hline G29 & $\begin{array}{l}\text { Glucose } \\
\text { Fructose }\end{array}$ & $\begin{array}{c}4119 \pm 181 \\
\mathrm{ND}\end{array}$ & $\underset{\text { ND }}{108 \pm 11}$ & $\begin{array}{c}1748 \pm 197 \\
316\end{array}$ \\
\hline B31 & $\begin{array}{l}\text { Glucose } \\
\text { Fructose }\end{array}$ & $\begin{array}{l}8090 \pm 240 \\
7958\end{array}$ & $\begin{array}{l}471 \pm 66 \\
356\end{array}$ & $\frac{1321}{306} \pm 338$ \\
\hline
\end{tabular}

ND, Not determined.

fructose uptake was observed in glucose-grown A37, but was significantly augmented following growth on fructose (Fig. 1). Conversely, the two other mutants, G29 and B31, possessed more EII fru activity than the parental strain after growth on glucose. Of particular interest was the fact that glucose-grown B31 exhibited as much fructose PTS activity as fructose-grown cells. Uptake studies with this strain indicated that the substrates of the mannose PTS (glucose, mannose and 2DG) did not interfere with fructose uptake in either glucose- or fructose-grown cells (Fig. 2). These results suggested that $S$. salivarius possessed a specific inducible EII fru that was expressed in glucose-grown cells of mutants G29 and B31, but subjected to glucose repression in mutant A37, although a basal level of EII fru activity was observed in this mutant after growth in glucose. This phenotypic difference suggested that the mutants were not all mutated on the gene encoding III ${ }^{\text {man }}$, although all of them were lacking IIIman (Gauthier et al., 1990). Therefore, IIIman could not be considered as a regulatory component involved in the control of EII fru synthesis.

In order to identify the proteins of the fructose PTS of $S$. salivarius, and to confirm its derepression in glucosegrown cells of strains G29 and B31, membranes and cytoplasm of the parental and mutant strains were separately incubated in the presence of [ $\left.{ }^{32} \mathrm{P}\right] \mathrm{PEP}, \mathrm{EI}$ and $\mathrm{HPr}$, and the phosphoproteins were resolved by electro-

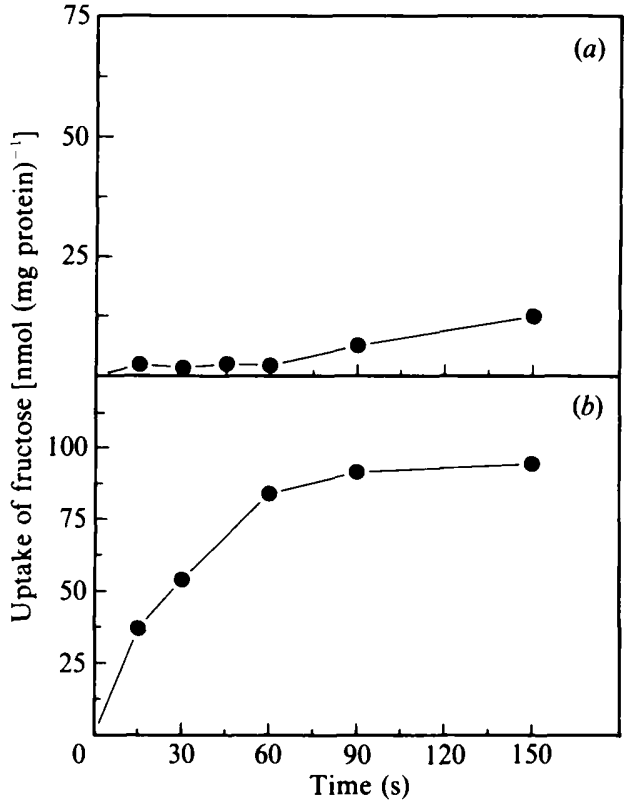

Fig. 1. Fructose uptake by $(a)$ glucose-grown or $(b)$ fructose-grown cells of mutant strain A37. Cells were cultured in the presence of $0.2 \%$ sugar and harvested at mid-exponential phase. Uptake experiments were carried out at $10^{\circ} \mathrm{C}$ in $50 \mathrm{~mm}$-sodium phosphate buffer (pH 7.0), containing $10 \mathrm{~mm}$-iodoacetate and $0.05 \mathrm{~mm}-\left[{ }^{14} \mathrm{C}\right]$ fructose [1 $\left.\mu \mathrm{Ci} \mu \mathrm{mol}^{-1}\left(37 \mathrm{kBq} \mu \mathrm{mol}^{-1}\right)\right]$.

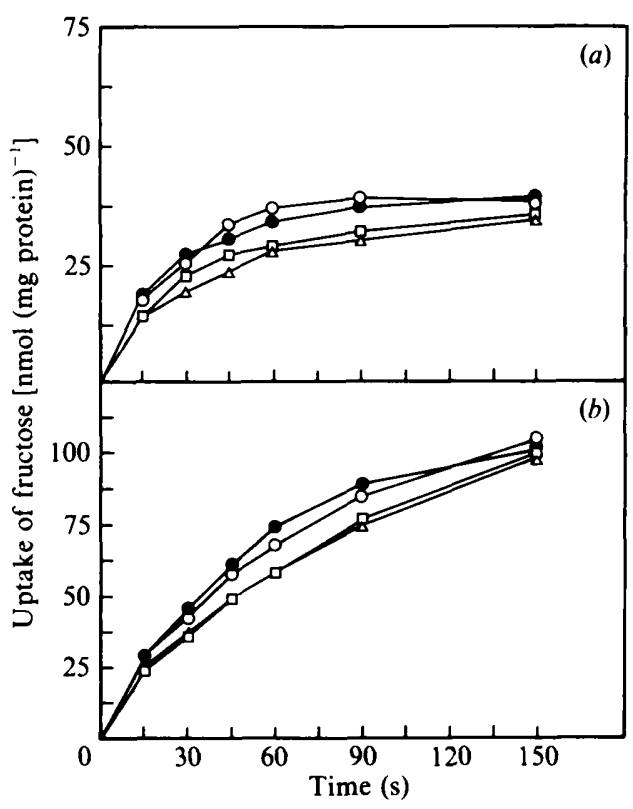

Fig. 2. Fructose uptake by $(a)$ glucose-grown or $(b)$ fructose-grown cells of mutant strain B31 in the presence of no sugar $(\bullet), 250 \mu \mathrm{M}$-glucose $(O), 250 \mu \mathrm{M}$-mannose $(\square)$ or $250 \mu \mathrm{M}-2 \mathrm{DG}(\Delta)$. Experimental procedures were as described in the legend to Fig. 1 . 
phoresis and detected by autoradiography. Results obtained with the membrane fraction of the wild-type strain are shown in Fig. 3. Apart from the soluble proteins EI and HPr that were added to the incubation medium, the only major labelled proteins found in membrane from glucose- and mannose-grown cells were the two forms of III ${ }^{\text {man }}$ (Fig. 3, lanes 1 and 3) (Bourassa et al., 1990). No phosphoprotein corresponding to EII ${ }^{\text {man }}$ $\left(M_{\mathrm{r}} 42600\right)$ (Bourassa et al., 1990) was observed in any membrane fraction suggesting that the enzyme, like the corresponding protein of E. coli (Erni \& Zanolari, 1985), has no phosphorylation site, or that the phosphoryl bond is unstable. When cells of $S$. salivarius were grown on fructose, a major phosphoprotein with an $M_{\mathrm{r}}$ of 57500 was specifically induced (Fig. 3, lane 2). This protein was not observed in cells grown on other sugars (glucose, mannose, lactose and sucrose). It was not found in the cytoplasmic fraction and its phosphorylation was dependent upon the presence of EI and HPr. The addition to the reaction medium of partially purified III ${ }^{\text {man }}$, unlabelled ATP or antibodies directed against III ${ }^{\text {man }}$ had no effect on the phosphorylation of this protein (data not shown). Addition to the reaction medium of fructose, but not glucose, caused the dephosphorylation of the protein (not shown). These results suggested that the $57.5 \mathrm{kDa}$ phosphoprotein was an inducible EII fru that was similar in size to EII fru from $E$. coli $\left(M_{\mathrm{r}} 57500\right)$ (Waygood et al., 1984; Prior \& Kornberg, 1988) and to EII fru from Rhodopseudomonas sphaeroides $\left(M_{\mathrm{r}} 55000\right)$ (Lolkema et al., 1985).

In agreement with EII fru activities reported in Table 1 and with fructose uptake determinations performed with the mutants (Figs 1 and 2), the phosphoprotein corresponding to EII fru was detected only in mutants G29 and B31 after growth on glucose (Fig. 4). This protein was, however, present in all the mutant strains after growth on fructose (data not shown). The results also confirmed that the mutants possess the high-molecular-mass form of III ${ }^{\text {man }}$ but are devoid of the other form (Gauthier et al., 1990). Other minor membrane phosphoproteins with molecular masses slightly greater than that of EI were also detected (Fig. 4). The function of these phosphoproteins is unknown. However, the fact that their phosphate bond was heat-labile, unlike the phosphateEI bond, indicated that they were not modified forms of this general PTS protein.

In enterobacteria (Geerse et al. 1989; Kornberg \& Elvin, 1987; Sutrina et al., 1988), S. mutans (Gauthier et al., 1984) and B. subtilis (Martin-Verstraete et al., 1990) more than one specific protein is involved in the fructose PTS. However, no other phosphoprotein specifically induced by fructose could be detected in $S$. salivarius following [32 P]PEP-dependent phosphorylation experiments performed with either the membrane or the

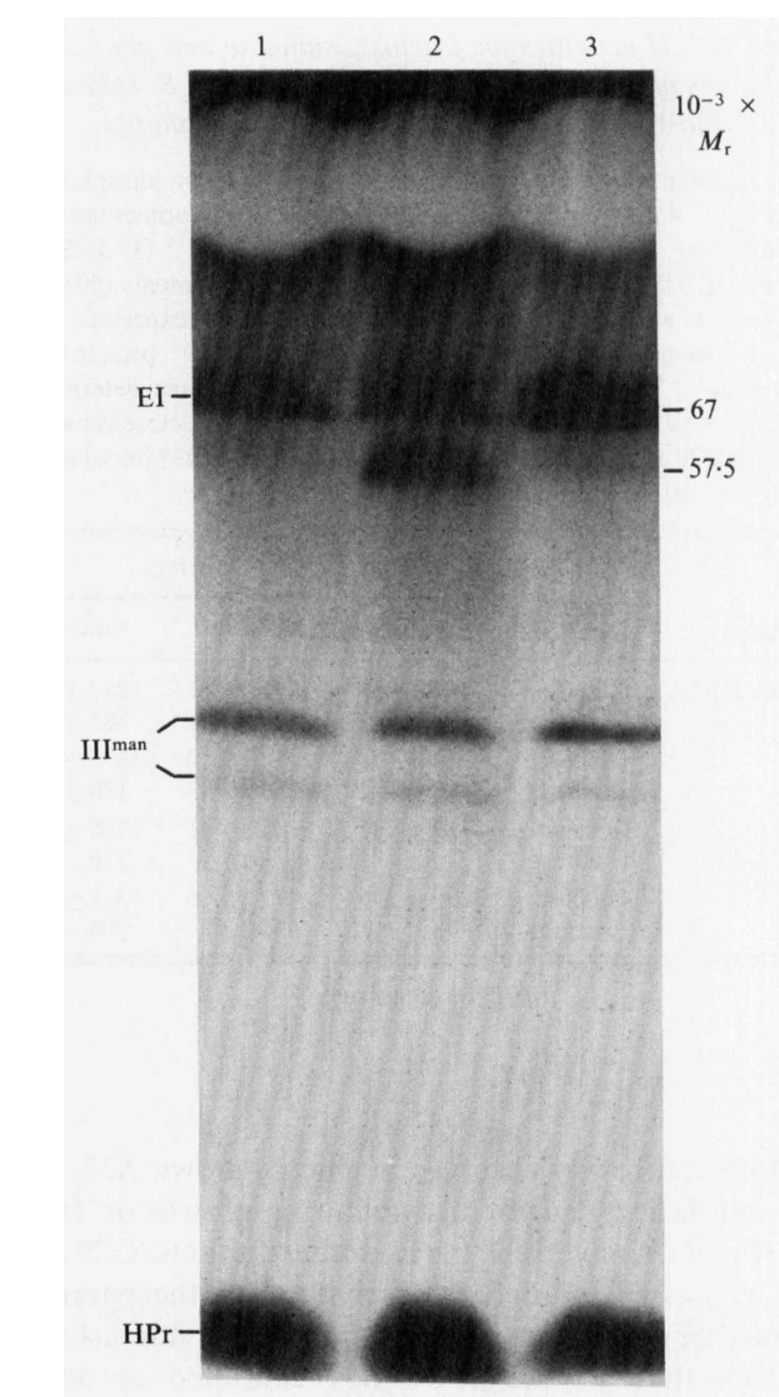

Fig. 3. [ ${ }^{32}$ P]PEP-dependent phosphorylation of membrane proteins prepared from wild-type cells of $S$. salivarius grown on glucose (lane 1), fructose (lane 2) and mannose (lane 3 ). The samples were analysed by SDS-PAGE with the resolving gel containing $12 \%$ acrylamide, followed by autoradiography. Prior to electrophoresis, samples were incubated for $6 \mathrm{~min}$ with $0.1 \mathrm{mM}-\left[{ }^{32} \mathrm{P}\right] \mathrm{PEP}$ (specific activity, $10^{6}$ c.p.m. nmol ${ }^{-1}$ ).

cytoplasmic fraction. Moreover, using an in vitro PTS assay, we tried to stimulate EII fru activity in membranes of the parental strain by adding a homologous membrane-free cellular extract to the reaction medium, but no increase in activity was observed. It can be argued, however, that the levels of the other putative fructose PTS proteins were too low or the proteins too unstable to be detected by these techniques. It was previously shown that antibodies directed against EI, HPr and III $I^{\text {man }}$ of $S$. salivarius cross-reacted with the proteins of $S$. mutans (Bourassa et al. 1990; Gauthier et al., 1984; Thibault \& 


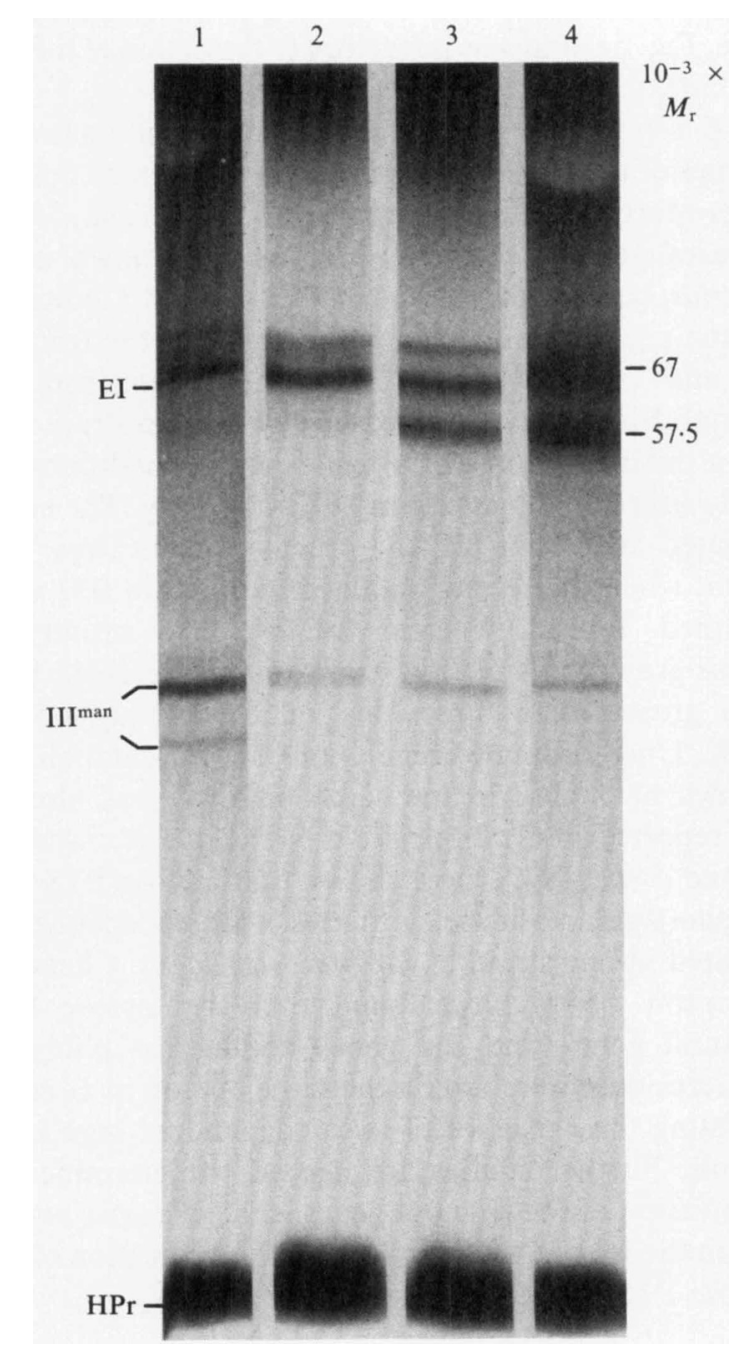

Fig. 4. [ $\left.{ }^{32} \mathrm{P}\right] \mathrm{PEP}$-dependent phosphorylation of membrane proteins of wild-type Streptococcus salivarius and the mannose-PTS-negative mutants A37, G29 and B31 grown on glucose. Lanes: 1, wild-type; 2, A37; 3, G29; 4, B31. Experimental procedures were as described in the legend to Fig. 3.

Vadeboncoeur, 1985). This prompted us to look for the presence of III fru in $S$. salivarius by Western blot experiments using antibodies directed against the III fru of S. mutans (Gauthier et al., 1984). However, no positive reaction was observed, suggesting once more an absence of III fru in $S$. salivarius. Nevertheless, this result may also be explained by a lack of cross-reaction between antiIII $^{\text {fru }}$ of $S$. mutans and the protein of $S$. salivarius. One may also hypothesize that the high-molecular-mass form of III ${ }^{\text {man }}$, still present in the mutants, was also a IIIfru. However, antibodies directed against III ${ }^{\text {man }}$ had no effect on the PEP-dependent phosphorylation of fructose by membranes of the mutant strains (data not shown)
Table 2. Phosphofructokinase activities in glucose- or fructose-grown cells of Streptococcus salivarius (wild-type) and mannose-PTS-negative mutants

The values are the mean of three determinations \pm SE.

\begin{tabular}{|c|c|c|c|}
\hline \multirow[b]{2}{*}{ Strain } & \multirow[b]{2}{*}{ Growth sugar } & \multicolumn{2}{|c|}{$\begin{array}{c}\text { Specific activity } \\
{\left[\mu \mathrm{mol}(\mathrm{mg} \text { protein })^{-1} \min ^{-1}\right.}\end{array}$} \\
\hline & & 1-PFK & 6-PFK \\
\hline ATCC 25975 & $\begin{array}{l}\text { Glucose } \\
\text { Fructose }\end{array}$ & $\begin{array}{l}0.49 \pm 0.16 \\
1.35 \pm 0.35\end{array}$ & $\begin{array}{l}4.11 \pm 0.85 \\
3.78 \pm 0.85\end{array}$ \\
\hline A37 & $\begin{array}{l}\text { Glucose } \\
\text { Fructose }\end{array}$ & $\begin{array}{l}0.30 \pm 0.08 \\
0.89 \pm 0.17\end{array}$ & $\begin{array}{l}2.58 \pm 0.45 \\
2.24 \pm 0.25\end{array}$ \\
\hline G29 & $\begin{array}{l}\text { Glucose } \\
\text { Fructose }\end{array}$ & $\begin{array}{l}1.45 \pm 0.21 \\
1.71 \pm 0.84\end{array}$ & $\begin{array}{l}3.30 \pm 0.66 \\
3.20 \pm 0.53\end{array}$ \\
\hline B31 & $\begin{array}{l}\text { Glucose } \\
\text { Fructose }\end{array}$ & $\begin{array}{l}0.75 \pm 0.15 \\
1.54 \pm 0.34\end{array}$ & $\begin{array}{l}1.56 \pm 0.11 \\
0.31 \pm 0.08\end{array}$ \\
\hline
\end{tabular}

indicating that $\mathrm{III}^{\mathrm{man}}$ was not involved in this reaction. Cloning and sequencing of the fructose PTS genes of $S$. salivarius are needed to solve the problem of III fru in this organism. The absence of an FPr component in $S$. salivarius is, however, compatible with the results obtained with Staphylococcus aureus since pts $H$ mutants of this species do not ferment fructose suggesting that the FPr protein is lacking (Reizer et al., 1989).

The phosphorylation of fructose by the inducible EII fru of E. coli (Ferenci \& Kornberg, 1974), Aerobacter aerogenes (Walter \& Anderson, 1973) and S. mutans (Gauthier et al., 1984) gives rise to F1P that is further metabolized to fructose diphosphate (FDP) by 1-PFK. In order to verify the existence of this metabolic pathway in $S$. salivarius, we measured 1-PFK and 6-PFK activities in the wild-type and mutant strains. The results outlined in Table 2 demonstrate that 1-PFK activity generally increased following growth of the cells on fructose in comparison with cells grown on glucose, while 6-PFK activity was not affected, except for strain B31 in which it decreased. This increase of 1-PFK activity in fructose-grown cells suggested that EII fru of $S$. salivarius phosphorylated fructose at the $\mathrm{C}-1$ position. This was confirmed by paper chromatographic analysis of the PTS reaction products. The product resulting from the PEPdependent phosphorylation of fructose by membranes of glucose-grown wild-type cells migrated at a position corresponding to F6P (9-12 cm from the origin, Fig. 5a). Incubation of this substance with 6-PFK and ATP gave rise to a product that migrated at a position corresponding to FDP $(2-4 \mathrm{~cm}$ from the origin, Fig. $5 b)$. The product obtained with membranes from fructose-grown cells of the mannose-PTS-defective strain, A37, migrated at a position corresponding to F1P $(7-10 \mathrm{~cm}$ from the 


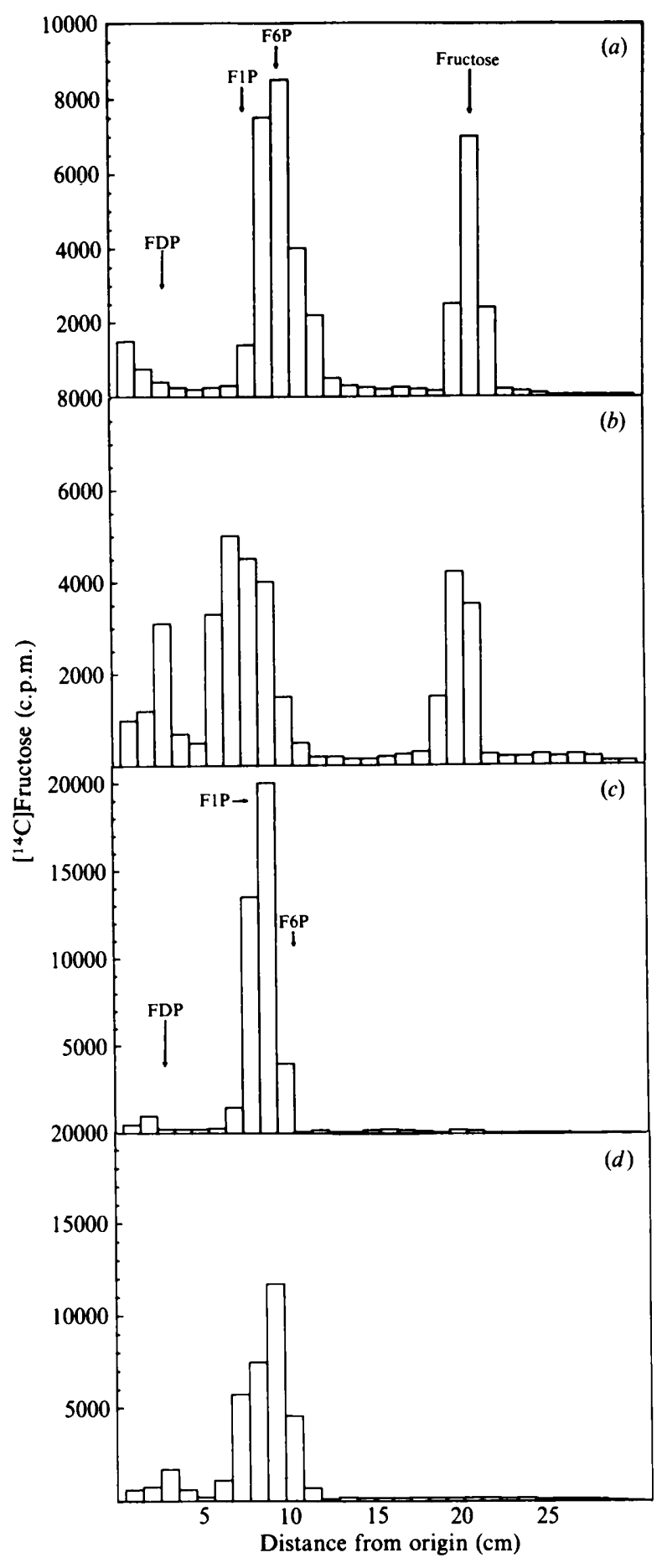

Fig. 5. Identification of reaction products by paper chromatography. The PEP-dependent phosphorylation of $\left[{ }^{14} \mathrm{C}\right]$ fructose was carried out in a mixture containing $1 \mathrm{mM}-\left[{ }^{14} \mathrm{C}\right]$ fructose $\left[0.5 \mathrm{Ci} \mathrm{mol}^{-1}\right.$ (18.5 GBq mol-1$)$ ], 4 mM- $\mathrm{MgCl}_{2}$, $2 \mathrm{mM}-\mathrm{PEP}, 2 \mathrm{~mm}-2$-mercaptoethanol, $10 \mathrm{mM}-\mathrm{NaF}, 267 \mu \mathrm{g}$ membranes, $115 \mu \mathrm{g} \mathrm{HPr}$ and $2 \mu \mathrm{g} \mathrm{EI}$ in 5 mM-triethanolamine buffer ( $\mathrm{pH} 7.0)$. After $180 \mathrm{~min}$ incubation at $37^{\circ} \mathrm{C}$, the reaction was stopped by heating the mixtures at $100^{\circ} \mathrm{C}$ for $2 \mathrm{~min}$. Arrows indicate the migration of fructose-phosphate standards. (a) Product obtained with membranes of glucose-grown cells of the wild-type strain ATCC 25975. (b) Same mixture as in (a) treated with origin, Fig. $5 c$ ) and was refractory to the action of 6-PFK (Fig. 5d).

In $E$. coli and $S$. typhimurium, the genes coding for the enzymes of the fructose PTS and 1-PFK form an operon (Jones-Mortimer \& Kornberg, 1974; Geerse et al., 1989). The arrangement of these genes is not known in $S$. salivarius, but results reported in Tables 1 and 2 indicated that the regulation of the genes coding for the fructose PTS and 1-PFK was not co-ordinate. For instance, although EII ${ }^{\text {fru }}$ activity increased eightfold in strain A37 after growth on fructose, the same culture conditions led to only a threefold increase in 1-PFK activity. The uncoordinated regulation of the fructose genes was also evident when the results obtained with strain B31 were examined. Indeed, whereas fructose PTS activity in glucose-grown cells of this strain was derepressed by a factor greater than three, this value was only 1.5 for 1-PFK. Unco-ordinated regulation of sugar-catabolizing enzymes belonging to the same pathway has already been reported in Gram-positive bacteria. For instance, Leblanc et al. (1979) have shown that lactose PTS and phospho- $\beta$-galactosidase activities were independently regulated in one strain of Streptococcus lactis. Chassy \& Thompson (1983) have found that the lactose PTS structural genes and the genes coding for phospho$\beta$-galactosidase were not on the same operon in L. casei, suggesting the existence of two independent regulatory controls. Further studies are needed to determine the organization of the fructose genes in S. salivarius and to explain the lack of co-ordination in the expression of the fructose PTS and 1-PFK genes.

\section{The cryptic glucose PTS of $S$. salivarius}

Previous results have already indicated the presence of an EII ${ }^{\text {ltc }}$ in the mutant strain G29 (Vadeboncoeur, 1984; Bourassa et al., 1990). The presence of this EIIgle is substantiated by the results presented in Table 1 showing that membranes isolated from glucose-grown cells of the mannose-PTS-defective mutant strains, A37, G29 and B31, possessed low EII ${ }^{\text {man }}$ activity but high EII'lc activity. The phosphorylation of glucose by this alternative glucose PTS was not inhibited by mannose, fructose, galactose or lactose, indicating the tight specificity of the system, contrasting with the broad specificity of the mannose PTS (Bourassa et al., 1990). That this EIIgle activity was involved in glucose utilization in the mutants was suggested by the fact that EII ${ }^{\text {glc }}$ activity (Table 1), as well as glucose transport and the rate of acid production from glucose by resting cells (data not

6-PFK before chromatography. (c) Products obtained with membranes of fructose-grown cells of the mannose-PTS-negative mutant A37. (d) Same mixture as in $(c)$ treated with 6-PFK before chromatography. 


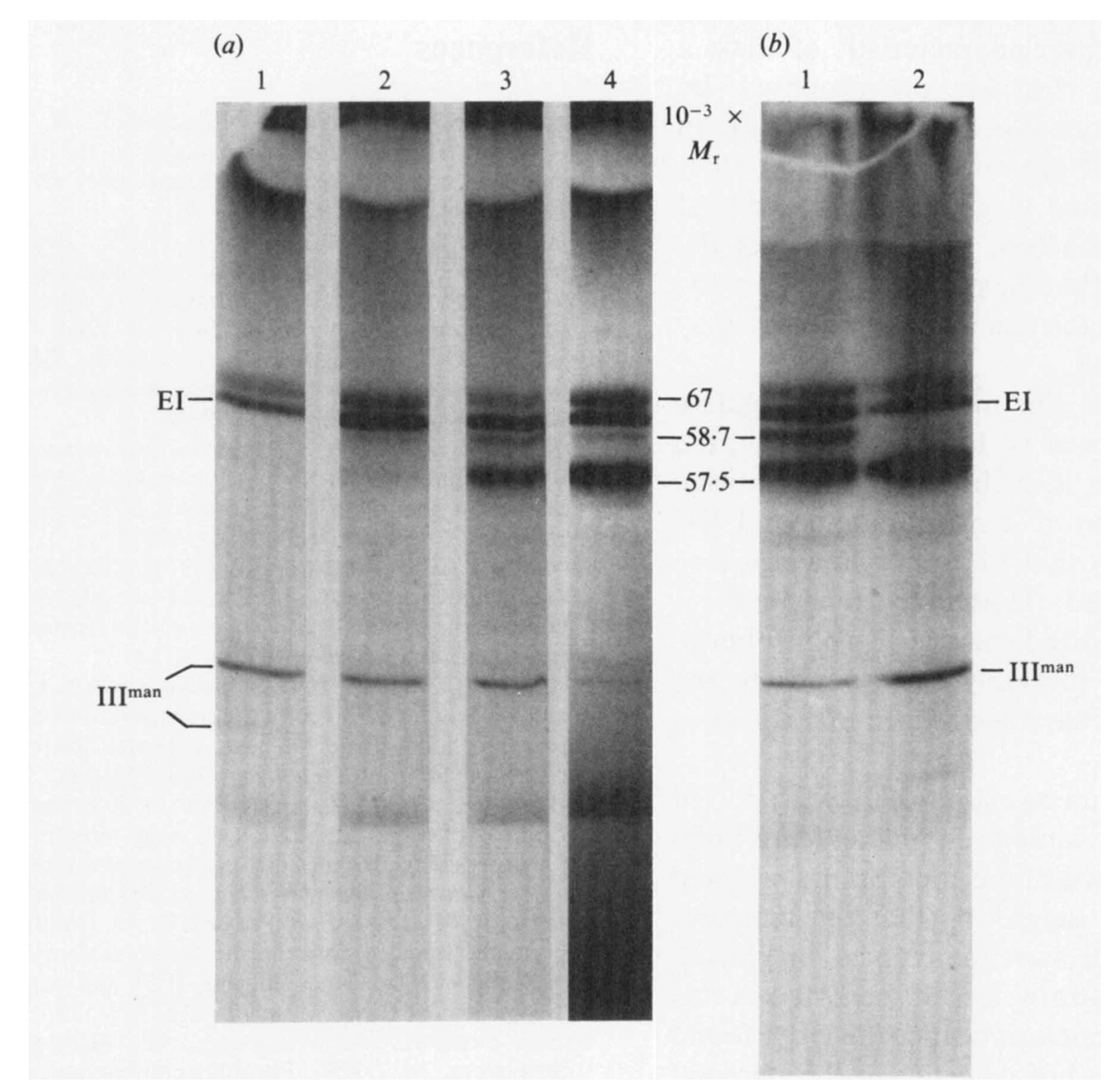

Fig. 6. [ ${ }^{32}$ P]PEP-dependent phosphorylation of membrane proteins. (a) Experiments performed with glucose-grown cells of wild-type strain (1), mutant A37 (2), mutant G29 (3) and mutant B31 (4). (b) Experiments performed with membranes from mutant G29 after growth on glucose (1) and fructose (2). The samples were analysed by SDS-PAGE with resolving gel containing $10 \%$ acrylamide. Other experimental procedures were as described in the legend to Fig. 3.

shown), were simultaneously decreased five- to eightfold after growth of the mutants on fructose.

In order to identify the specific proteins of this glucose PTS, membranes as well as cytoplasm from glucosegrown cells of the parent and mutant strains were incubated in the presence of $\left.{ }^{32} \mathrm{P}\right] \mathrm{PEP}, \mathrm{EI}$ and $\mathrm{HPr}$, and analysed for phosphoproteins by SDS-PAGE. Such experiments conducted on $12 \%$ acrylamide gels have demonstrated the existence of EII fru $\left(M_{\mathrm{r}} 57500\right)$ but did not reveal other EIIs in glucose-, fructose-, and mannosegrown cells of the parental or mutant strains (Figs 3 and 4). However, because many EIIs have similar molecular mass (Meadow et al., 1990), resolution of several EIIs by electrophoresis on a $12 \%$ acrylamide gel in the presence of SDS might result in overlap. We therefore searched for EII ${ }^{\text {glc }}$ on gels containing $10 \%$ acrylamide. This concentration of acrylamide did not retain the low-molecularmass protein HPr on the gel but allowed for a better resolution of the high-molecular-mass proteins. Under these conditions we were able to detect, in membranes from glucose-grown cells of the mutant strains, an additional phosphoprotein with an $M_{\mathrm{r}}$ of 58700 (Fig. $6 a$, lanes 2, 3 and 4). This protein was not detected in the cytoplasm, and its phosphorylation depended on the presence of the general PTS proteins HPr and EI, but not of IIIman (data not shown). Growth of the mutant strains on fructose resulted in the disappearance of this phosphoprotein (Fig. 6b, lane 2). The concomitant loss of the $58.7 \mathrm{kDa}$ protein and glucose PTS activity in fructose-grown cells suggested that the $58.7 \mathrm{kDa}$ protein was a membrane component of the alternative glucose PTS detected in the mannose-PTS-defective mutant strains of $S$. salivarius.

The EII ${ }^{\text {glc }}$ of Bacillus subtilis was recently cloned and sequenced (Gonzy-Tréboul et al., 1989; Sutrina et al., 1990). The permease consists of a single polypeptide chain that migrates on an SDS gel as a $75 \mathrm{kDa}$ protein and possesses a C-terminal III-like domain (Sutrina $e t$ al., 1990). The $M_{\mathrm{r}}$ of EII ${ }^{\text {glc }}$ of $S$. salivarius $(58700)$ as well as the chemical properties of the phosphate bond (heat- 
and acid-labile) were however characteristic of Class 2 EIIs, according to the classification proposed by Meadow et al. (1990). Enzymes of this class function in tandem with a separate III protein. However, no other phosphoprotein was detected in glucose-grown cells of the mutant strains. Nevertheless, as in the case of the fructose system, it may be that the protein levels were too low or the phosphoprotein too unstable to be detected by the technique that we used.

The EII ${ }^{\text {lc }}$ identified in the mannose-PTS-negative mutant strains of $S$. salivarius is, to our knowledge, the only specific EII ${ }^{\text {glc }}$ so far identified in Gram-positive streptococci. Solubilization of a membrane-bound EII from Enterococcus faecalis that phosphorylated glucose has already been reported (Hudig \& Hengstenberg, 1980). However, the solubilized enzyme also phosphorylated mannose and more probably corresponds to the mannose PTS recently characterized in $S$. salivarius (Bourassa et al., 1990).

In a previous study (Bourassa et al., 1990), we reported that anti-III $I^{\text {man }}$ antibody almost completely inhibited glucose PTS activity of wild-type membranes isolated from glucose-grown cells suggesting that the mannose PTS was the unique PTS system involved in glucose transport in the parental strain. Results reported in this paper substantiated this conclusion since the EII ${ }^{\text {glc }}$ found in the mutant strains was not detected in the parental strain (Fig. 6, lane 1) irrespective of what the growth conditions were. This suggested that the gene coding for EII ${ }^{\text {glc }}$ was cryptic in wild-type $S$. salivarius. Cryptic genes have been defined as genes that are not normally expressed during the lifetime of an organism, but which can be activated by genetic events (Hall et al. 1983). In the case reported here, activation of the cryptic EII ${ }^{\text {glc }}$ occurred in the three mutants lacking IIIman. We have already reported that this alternative glucose PTS has a lower affinity for glucose than the mannose PTS (Vadeboncoeur, 1984). Thus, a functional gene coding for a low affinity EII ${ }^{\text {lc }}$ would be disadvantageous to the parental strain of $S$. salivarius since the mannose PTS has a higher affinity for glucose. Expression of the gene in mannose-PTS-defective mutants, however, allows the cells to survive in glucose-containing media. Three other cryptic phosphotransferase systems involved in $\beta$-glucoside uptake have been reported in bacteria (Mahadevan et al., 1987; Kricker \& Hall, 1987; Parker \& Hall, 1990).

This research was supported by the Medical Research Council of Canada operating grant no. MT-6979 to Christian Vadeboncoeur. Sylvie Bourassa was supported by a studentship from the Fonds de la Recherche en Santé du Québec. We thank Dr Michel Frenette and Dr Luc Trahan for reading the manuscript. C.V. is a scholar of the Fonds de la Recherche en Santé du Québec.

\section{References}

Bourassa, S., Gauthier, L., Giguère, R. \& Vadeboncoeur, C. (1990). A III $^{\text {man }}$ protein is involved in the transport of glucose, mannose and fructose by oral streptococci. Oral Microbiology and Immunology 5, 288-297.

Chassy, B. M. \& Thompson, J. (1983). Regulation of lactosephosphoenolpyruvate-dependent phosphotransferase system and $\beta$-D-phosphogalactoside galactohydrolase activities in Lactobacillus casei. Journal of Bacteriology 154, 1195-1203.

ConRad, R. \& Schlegel, H. G. (1977). Different degradation pathways for glucose and fructose in Rhodopseudomonas capsulata. Archives of Microbiology 112, 39-48.

ERNI, B. \& Zanolari, B. (1985). The mannose-permease of the bacterial phosphotransferase system. Gene cloning and purification of the enzyme IIman/III man complex of Escherichia coli. Journal of Biological Chemistry 260, 15495-15503.

FERENCI, T. \& KoRnBerg, H. L. (1974). The role of phosphotransferase-mediated synthesis of fructose-1-phosphate and fructose-6-phosphate in the growth of Escherichia coli on fructose. Proceedings of the Royal Society of London 187, 105-119.

Gauthier, L., Mayrand, D. \& Vadeboncoeur, C. (1984). Isolation of a novel protein involved in the transport of fructose by an inducible phosphoenolpyruvate:fructose phosphotransferase system in $S$. mutans. Journal of Bacteriology 160, 755-763.

Gauthier, L., Bourassa, S., Brochu, D. \& Vadeboncoeur, C. (1990). Control of sugar utilization in oral streptococci. Properties of phenotypically distinct 2-deoxyglucose resistant mutants of Streptococcus salivarius. Oral Microbiology and Immunology 5, 352-359.

Geerse, R. H., Izzo, F. \& Postma, P. W. (1989). The phosphoenolpyruvate:fructose phosphotransferase system in Salmonella typhimurium: FPr combines enzyme III fru and pseudo-HPr activities. Molecular and General Genetics 216, 517-525.

Gonzy-Treboul, G., Zagorec, M., Rain-Guion, M. C. \& Steinmetz, M. (1989). Phosphoenolpyruvate : sugar phosphotransferase system of Bacillus subtilis: nucleotide sequence of ptsX, ptsH and the $5^{\prime}$-end of ptsI and evidence for a ptsHI operon. Molecular Microbiology 3, 103-112.

Hall, B. G., Yokoyama, S. \& Calhoun, D. H. (1983). Role of cryptic genes in microbial evolution. Molecular Biological Evolution 1, 109-124.

Hudig, H. \& Hengstenberg, W. (1980). The bacterial phosphoenolpyruvate-dependent phosphotransferase system. Solubilization and kinetic parameters of the glucose-specific membrane bound enzyme II component of Streptococcus faecalis. FEBS Letters 114, 103-106.

JONES-MORTIMER, M. C. \& KoRNBERG, H. L. (1974). Genetic analysis of fructose utilization by Escherichia coli. Proceedings of the Royal Society of London (B) 187, 121-131.

KorNBerg, H. L. \& Elvin, C. M. (1987). Location and function of $f r u C$, a gene involved in the regulation of fructose utilization by Escherichia coli. Journal of General Microbiology 133, 341-346.

KRICKER, M. \& HALL, B. G. (1987). Biochemical genetics of the cryptic gene system for cellobiose utilization in Escherichia coli K-12. Genetics 115, 419-429.

LAEMMLI, U. K. (1970). Cleavage of structural proteins during the assembly of the head of bacteriophage T4. Nature, London 227, 680-685.

Leblanc, D. J., Crow, V. L., Lee, L. N. \& Garon, C. F. (1979). Influence of the lactose plasmid on the metabolism of galactose by Streptococcus lactis. Journal of Bacteriology 137, 878-884.

Lolkema, J. S., Ten Hoene-DuUrkens, R. H. \& Robillard, G. T. (1985). The phosphoenolpyruvate-dependent fructose-specific phosphotransferase system in Rhodopseudomonas sphaeroides. European Journal of Biochemistry 149, 625-631.

Mahadevan, S., Reynolds, A. E. \& Wright, A. (1987). Positive and negative regulation of the bgl operon of Escherichia coli. Journal of Bacteriology 169, 2570-2578.

Martin-Verstraete, I., Débarbouillé, M., Klier, A. \& RApoport, G. (1990). Levanase operon of Bacillus subtilis includes a fructosespecific phosphotransferase system regulating the expression of the operon. Journal of Molecular Biology 214, 657-671. 
Mattoo, R. S. \& Waygood, E. B. (1983). An enzymatic method for [32P]phosphoenolpyruvate synthesis. Analytical Biochemistry 128 , 245-249.

Meadow, N. D., Fox, D. K. \& Roseman, S. (1990). The bacterial phosphoenolpyruvate:glucose phosphotransferase system. Annual Review of Biochemistry 59, 497-542.

Parker, L. L. \& HalL, B. G. (1990). Characterization and nucleotide sequence of the cryptic cel operon of Escherichia coli K12. Genetics 124, 455-471.

Prior, T. I. \& Kornberg, H. L. (1988). Nucleotide sequence of fruA, the gene specifying enzyme IIfru of the phosphoenolpyruvatedependent sugar phosphotransferase system in Escherichia coli K 12. Journal of General Microbiology 134, 2757-2768.

Reizer, J., Saier, M. H., JR, Deutscher, J., Grenier, F., Thompson, J. \& HENGSTENBERG, W. (1988). The phosphoenolpyruvate: sugar phosphotransferase system in Gram-positive bacteria: properties, mechanism and regulation. CRC Critical Reviews in Microbiology 15, 297-338.

Reizer, J., Sutrina, S. L., Saier, M. H., JR, Stewart, G. C., Peterkofsky, A. \& Reddy, P. (1989). Mechanistic and physiological consequences of $\mathrm{HPr}$ (ser) phosphorylation on the activities of the phosphoenolpyruvate:sugar phosphotransferase system in Gram-positive bacteria: studies with site-specific mutants of $\mathrm{HPr}$ EMBO Journal 8, 2111-2120.

Rodrigue, L., Lacoste, L., Trahan, L. \& Vadeboncoeur, C. (1988). Effect of nutritional constraints on the biosynthesis of the components of the phosphoenolpyruvate:sugar phosphotransferase system in a fresh isolate of Streptococcus mutans. Infection and Immunity 56, 518-522.

Sutrina, S. L., Chin, M. A., Esch, F. \& Saier, M. H., JR (1988). Purification and characterization of the fructose-inducible HPr-like protein, FPr, and the fructose-specific enzyme III of the phosphoenolpyruvate: sugar phosphotransferase system of Salmonella typhimurium. Journal of Biological Chemistry 263, 5061-5069.

Sutrina, S. L., Reddy, P., Saier, M. H., JR \& Reizer, J. (1990). The glucose permease of Bacillus subtilis is a single polypeptide chain that functions to energize the sucrose permease. Journal of Biological Chemistry 265, 18581-18589.

Thibault, L. \& Vadeboncoeur, C. (1985). Phosphoenolpyruvatesugar phosphotransferase transport system of Streptococcus mutans: purification of HPr and Enzyme I and determination of their intracellular concentrations by rocket immunoelectrophoresis. Infection and Immunity 50, 817-825.

THOMpson, J. (1987). Sugar transport in the lactic acid bacteria. In Sugar Transport and Metabolism in Gram-positive Bacteria, pp. 13-38. Edited by J. Reizer and A. Peterkofsky. Chichester: Ellis Horwood.

Towbin, H., Staehelin, T. \& Gordon, J. (1979). Electrophoretic transfer of proteins from polyacrylamide gels to nitrocellulose sheets. Procedure and some applications. Proceedings of the National Academy of Sciences of the United States of America 76, 4350-4354.

VADEBONCOEUR, C. (1984). Structure and properties of the phosphoenolpyruvate:glucose phosphotransferase system of oral streptococci. Canadian Journal of Microbiology 30, 495-502.

VADEBoncoeur, C. \& GaUTHIER, L. (1987). The phosphoenolpyruvate:sugar phosphotransferase system of Streptococcus salivarius. Identification of a III ${ }^{\text {man }}$ protein. Canadian Journal of Microbiology 33, 118-122.

VADEBONCOEUR, C. \& Trahan, L. (1982). Glucose transport in Streptococcus salivarius. Evidence for the presence of a distinct phosphoenolpyruvate:glucose phosphotransferase system which catalyses the phosphorylation of $\alpha$-methyl glucoside. Canadian Journal of Microbiology 28, 190-199.

Vadeboncoevr, C., Mayrand, D. \& Trahan, L. (1982). A comparative study of enzymes involved in glucose phosphorylation in oral streptococci. Journal of Dental Research 61, 60-65.

W ALTER, R. W. \& ANDERSON, R. L. (1973). Evidence that the inducible phosphoenolpyruvate:D-fructose-1-phosphotransferase system of Aerobacter aerogenes does not require 'HPr'. Biochemical and Biophysical Research Communications 52, 93-97.

Waygood, E. B., Mattoo, R. L. \& Peri, K. G. (1984). Phosphoproteins and the phosphoenolpyruvate:sugar phosphotransferase system in Salmonella typhimurium and Escherichia coli: evidence for III Mannose, IIIFructose, III Glucitol and the phosphorylation of Enzyme II $^{\text {Mannitol }}$ and Enzyme II ${ }^{N-A c e t y l g l u c o s a m i n e}$. Journal of Cellular Biochemistry 25, 139-159.

Waygood, E. B., Mattoo, R. L., Erickson, E. \& Vadeboncoeur, C. (1986). Phosphoproteins and the phosphoenolpyruvate : sugar phosphotransferase system of Streptococcus salivarius. Detection of two different ATP-dependent phosphorylations of the phosphocarrier protein HPr. Canadian Journal of Microbiology 32, 310-318. 